\title{
Belgeo
}

Revue belge de géographie

\section{Against all odds: poor people jumping scales and the genesis of an urban policy in Flanders, Belgium}

De schaalsprong van de armen en de onverhoopte ontwikkeling van een stedelijk

beleid in Vlaanderen

Contre toute attente : changement d'échelle pour les défavorisés et émergence

d'une politique urbaine en Flandre (Belgique)

Maarten Loopmans, Justus Uitermark and Filip De Maesschalck

\section{OpenEdition}

Electronic version

URL: http://journals.openedition.org/belgeo/15726

DOI: $10.4000 /$ belgeo. 15726

ISSN: 2294-9135

Publisher:

National Committee of Geography of Belgium, Société Royale Belge de Géographie

Printed version

Date of publication: 30 September 2002

Number of pages: $243-258$

ISSN: $1377-2368$

\section{Electronic reference}

Maarten Loopmans, Justus Uitermark and Filip De Maesschalck, « Against all odds: poor people jumping scales and the genesis of an urban policy in Flanders, Belgium », Belgeo [Online], 3 | 2002, Online since 01 October 2002, connection on 30 April 2019. URL : http://journals.openedition.org/ belgeo/15726 ; DOI : 10.4000/belgeo.15726

This text was automatically generated on 30 April 2019.

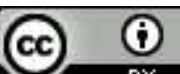

Belgeo est mis à disposition selon les termes de la licence Creative Commons Attribution 4.0 International. 


\section{Against all odds: poor people jumping scales and the genesis of an urban policy in Flanders, Belgium}

De schaalsprong van de armen en de onverhoopte ontwikkeling van een stedelijk beleid in Vlaanderen

Contre toute attente : changement d'échelle pour les défavorisés et émergence d'une politique urbaine en Flandre (Belgique)

Maarten Loopmans, Justus Uitermark and Filip De Maesschalck

\section{Introduction}

1 In this paper, we undertake an investigation of the emergence of urban policy in Flanders. Unlike other West-European countries, such as the Netherlands or the United Kingdom, urban policy in Belgium (and Flanders) remained underdeveloped until recently. We try to explain the historical lack of explicit political attention for cities as well as the emergence of an ambitious - albeit underfunded - urban policy in recent years. We situate our analysis within a broader literature on state action, urban governance and re-scaling. This literature is discussed in the first section.

In the second section, we describe how urban problems have been neglected in Belgium from the 19th century onwards. While in other West-European countries the emergence of the «New Social Movements» in the 1960s and 1970s provoked (renewed) interest in the city, this did not lead to the development of any national urban policy initiative in Belgium or Flanders.

In the third section, we discuss how the successive electoral victories of the extremeright party Vlaams Blok and the reaction to this threat by more established parties finally serve as a lever to draw attention to the fate of deprived urban areas and their dwellers. Furthermore we focus on the resulting development of an urban policy in Flanders (Social 
Impulse Fund or SIF) that focuses (more than in other countries) on the living conditions of the poor in disadvantaged neighbourhoods.

In the last section, we describe the new direction urban policy has taken since the latest elections in 1999. Urban policy has reoriented towards urban competitiveness and the quality of life for higher income groups. The question is now to what extent the institutional footprint of the SIF is able to maintain a social orientation in the new urban policy.

\section{On «scale», path-dependency and ruptures}

5 It is very difficult to pinpoint where exactly urban policy comes from; what processes or events do we need to study in order to explain the history of urban policy in a particular case? The answer to this question will generally vary according to the way in which one contextualises the state (MacLeod \& Goodwin, 1999). How to explain the actions of the state remains one of the most challenging enterprises for the social sciences and we do not wish to try to settle nor review these general discussions here. We do, however, want to put forward a research strategy that is rooted in state theory (see also Uitermark, 2003a). In particular we want to argue that recent theorizing on scale, governance and state policy provides an interesting angle from which to study the process of policy formation (for overviews, see MacLeod \& Goodwin, 1999; Uitermark, 2002a). Theorizing on scale departs from the overarching idea that «scale» is not simply a by-product of social processes - «scale matters» in at least two fundamental ways. First, the scale on which actors operate determines their power to affect social processes. For example, it is generally far more difficult for local pressure groups to exert power on a national scale than on a local scale. This means that, if decision-making processes are shifted from the local to the national level, local pressure groups lose some of their power to affect political decisions and, hence, their power to manipulate social processes according to their own beliefs and interests. The second assumption, which is actually implicit in the first, is that scale is essentially malleable. It is not a given form but the product of social processes, which means that it matters politically.

While there may be consensus on these basic propositions, different accounts deal with them in different ways. Like most critical approaches to the state (see Jessop, 1982, 1990), recent theorising on scale, scalar configurations and re-scaling falls more or less within one of two categories. Some accounts emphasise political struggle and see the emergence of scalar configurations as temporal and contingent outcomes of these struggles. Others take account of general shifts in the organisation of capitalism and argue that processes of re-scaling result both from reorganisation and the facilitation of this reorganisation. These positions will be referred to as class-theoretical and capital-theoretical. It has to be emphasised that authors writing on re-scaling do not choose between either position; to the extent that distinct positions have been articulated, authors generally agree that both struggles and general shifts, in as far as they can be analytically separated, should be taken into account (cf. Brenner, 2001; Swyngedouw, 1997a, 1997b). However, by giving explicit attention to each position in turn, we can identify both the opportunities and limits for an analysis of Belgian urban policy as a re-scaling process.

7 The most concrete example of an account that emphasises struggles, is Smith's by now classic analysis of homeless vehicles in New York. Smith (1993) argues that homeless people were able to attract a considerable amount of attention because their vehicles 
increased their visibility. As a result, struggles that were usually fought out within the micro-spaces of benches and porches were now scaled up to the city level, which meant that the power of homeless people was (temporarily) dramatically increased - the homeless had «jumped scales». Another frequently cited example of a contested rescaling process is the formation of the European Union (see Devos, 2001; Smith, 1995; Swyngedouw, 2000). What kind of decisions are to be made on the European level is to a large extent determined by the power of actors to jump scales horizontally and vertically. Accounts that focus on the political aspect of re-scaling, i.e. the degree to which individual actors can make a difference, clearly have the merit of showing how every singly instance of re-scaling processes is tied up with the reconfiguration of power geometries, i.e. the extent to which actors have the ability to move across space and to which they can initiate and shape flows and interconnections over space (Massey, 1993, p. 61). However, it is equally clear that actions unfolded within an already highly uneven distribution of power inhibits some strategies and priviliges others. Generally speaking, strategies that do not fit the logic of the context in which they are adopted have a high chance of failure (see below). Thus, in order to understand the aggregate result of the individual behaviours, it is important to analyse the structural features of interrelationships in which these actors are involved.

Brenner $(1998,1999)$ has offered one of the most developed accounts of re-scaling processes from a capital-logic viewpoint. Although he follows Smith and Swyngedouw in arguing that scale should be understood as something contested and struggled over, his aim clearly is to give a general account of "glocalisation» processes (especially in Europe). Following Lefebvre, he states that capital and state eventually merge into the same spaces. In this account, because the shift from Fordism to an "unknown successor» is associated with an increased importance of urban and regional economic complexes and the internationalisation (globalisation) of economic activities. New scalar configurations are gradually taking a «glocal» form.

9 Although authors writing on re-scaling have generally been sensitive both to agency and structure, there is a real problem in understanding how to combine the two angles, from which we analyse social processes. Class-theoretical approaches do not explain why scalar configurations are usually relatively fixed and only periodically radically reconfigured. Moreover, these analyses necessarily have to be complemented by accounts of the political-economic context in which actors operate in order to understand the relative distribution of power, the issues involved and the extent to which the strategies and actions of individual actors will lead to the crystallasation of new scalar configurations. Capital-theoretical accounts provide little opportunity to account for differences between countries and «exceptions to the rule». While these theoretical problems can not be solved here, we can at least develop some notions that can guide concrete research on urban policy.

One possible way to transcend the discrepancy between approaches that emphasise struggle and those that emphasise structural change, is to make clear how structure and agency are mutually constitutive (cf. Giddens, 1984; compare Jessop, 2001). One key notion that can be of use in this regard is that of «path-dependency» (see, e.g., Pierson, 2000), which we take to refer to a situation in which actors within a particular context modify their behaviour to contextual constraints and opportunities in such a way that the particularity of that context is reproduced. Coming back to the question of scale, this can mean, for example, that a Dutch organisation that seeks funding for its activities is more 
likely than its American counterpart to request funds from central government. Since the Dutch government is called upon relatively often, the degree of intervention (in terms of resources) and accountability for social problems remains high, which in turn increases the chance that it is called upon in the future. This example illustrates a general tendency: «established institutions generate powerful inducements that reinforce their own stability and further development» (Pierson, 2000, p. 255). With respect to scale, this means that both private parties and the state act in a (scale) selective manner with respect to their institutional environment; in spite of the rhetoric about giving the community (or regions, cities, etc.) a say, their actions are more likely to complement, adapt and reinforce an already existing structure than to develop truly new configurations in which the relative distribution of power is very much different from before (cf. Collinge, 1999; Jones, 1997; Uitermark, 2002b).

11 Nevertheless, there sometimes occur «critical conjunctures» in any process of socioeconomic development, i.e. periods of turbulency in which the basic features of political and social life are reconfigured. Typically these periods mark the end of a certain social or political episode in the history of a country or region, such as the Fordist era or the rule of a certain political party; they occur when a particular kind of political or economic organisation has reached its inner limits or is confronted with a significant external influence ${ }^{1}$. During these ruptures the networks of interdependency, that are intrinsic to any social organisation, are reconfigured. This also means that these ruptures can be accompanied by shifts in the balance of power, including the power of actors to act in and through the state (cf. Poulantzas, 1978; Jessop, 1990), i.e. to shape the state's policies (see also Uitermark, 2003b). Due to the fact that distributions of power are associated with the power of respective actors to exercise influence on diverse spatial scales, it is no incident that these ruptures coalesce with processes of scalar reconfiguration (see also Brenner, 2001).

12 We would like to argue that an understanding of these ruptures is key to a proper combination of class- and capital-theoretical accounts of scalar reconfigurations. In short, the argument runs as follows: even if actors - in our case, local politicians, academics, activists and welfare workers concerned with the fate of disadvantaged neighbourhoods continually try to exercise influence through scale politics, their actions are only likely to result in the crystallisation of relatively new «scalar fixes» during periods when previous configurations are facing a rupture. To substantiate and elaborate on this claim, we investigate, by means of a literature review, the development of an urban policy in Flanders, Belgium. First, we describe, the path-dependent development of the Belgian/ Flemish welfare state and explain why urban policies were not likely to emerge as soon as in other European countries. Then we discuss the electoral victories of the Vlaams Blok which signify to us the rupture that not only enabled the development of urban policy in Flanders, but is equally important for understanding the form and content of it. It empowered actors concerned with disadvantaged neighbourhoods to jump scales and influence policy at the regional and federal scale. Next, we try to establish to what extent recent developments justify the claim that this rupture has led to a lasting reconfiguration of institutional interdependencies that give actors concerned with the fate of disadvantaged neighbourhoods political leverage. Finally we argue that urban policy in Flanders might be taking a new turn in the near future. 


\title{
«Neglected cities»: the path dependent development of an anti-urban policy in Belgium
}

\author{
Spatial strategies of class struggle and the neglect of inner city \\ problems
}

13 In Belgium (and in Flanders), attention for urban problems has always been rather low on the central policy level. Still in 1989, Cheshire \& Hay conclude that «there does not exist in Belgium at either the national or regional level any real policy designed to combat urban decline» (Cheshire \& Hay, 1989). This lack of attention for urban problems can be explained by the specific power geometry in Belgian politics. Since 1884, the Catholic Church and bourgeoisie have occupied a hegemonic position in the Belgian political landscape, and spatial politics have been applied next to pillarisation to conserve this dominance and to hamper the rise of secularisation and the socialist movement in central working class neighbourhoods (Kesteloot \& De Maesschalck, 2001). The main goal was to avoid the spatial concentration of workers in the cities. The development of a dense network of public transport connecting the cities with the surrounding villages enabled commuting, rendering migration unnecessary. The stimulation of property acquisition and individual housing as an answer to the housing problem also drew skilled workers away from the central working class neighbourhoods to the urban fringe where land prices where cheap enough. Nonetheless, the bottom of the housing market was left untouched, enhancing the concentration of unskilled workers and the lumpenproletariat in inner city slums (Knops, 1981).

After the First World War, the socialist party gained power and stimulated social housing. They promoted collective living and supported the idea of the garden city. These initiatives were by-passed soon by a new Catholic law promoting individual housing again, and did not score much effect in the inner city either. The few garden cities that were realised were developed in the urban fringe where land prices were low. The housing cost, together with the cost for commuting was too high for lower income groups which did not improve the situation in inner city neighbourhoods (De Lannoy \& Kesteloot, 1990).

The pillarisation and spatial strategies of the Catholic party were more successful in Flanders than in Wallonia, where industrialisation and urbanisation had older roots. As a consequence, the Catholic party has its stronghold in Flanders, the socialist party in Wallonia. This territorial organisation of pillarisation means that the power configuration of parties is more stable at the local (subregional) level, each party running the risk of losing power on the level of the national state under the Belgian electoral system of equal representation. Therefore both parties had their interest in strengthening the municipal level. This resulted in a high level of local fiscal autonomy and a lack of impetus to change municipal borders into bigger entities (Terhorst \& Van de Ven, 1997; 1999).

\section{Grassroots protests and the false start of a local social urban renewal policy} acquisition in the periphery further dominated housing policy and led to a 
suburbanisation boom in the 1960s. House ownership now became an important element in the Fordist consumption-driven economic growth. New laws voted after the second World War stimulated massive, but still socially selective suburbanisation. At the same time, inner city neighbourhoods faced a decline of their residential function: the development of a Central Business District together with massive suburbanisation and the generalisation of car-ownership demanded more inner city space for offices and access roads. During the heighdays of the Fordist welfare state, in the 1950s and 1960s, the laws of 1953 and 1956 to stimulate slum clearance paved the way for large scale levelling of old inner city neighbourhoods in favour of office buildings and commercial functions. A series of inner city neighbourhoods were demolished for the construction of roads and office buildings, with Brussels North, where thousands of inhabitants were evicted, as the best example.

But in the 1960s and 1970s in Belgium, as elsewhere in Europe, inhabitants of deprived neighbourhoods who were under threat of urban restructuring started to mobilise against the «neglect» of their interests in national urban policy initiatives. Action groups and neighbourhood committees were flourishing, but did not receive much attention at the national level. Local fiscal autonomy in combination with territorial fragmentation and the fact that local mayors could be elected for a parliamentary seat as well were chiefly responsible for this neglect. Local fiscal autonomy and territorial fragmentation of city regions has disadvantaged central cities under the suburbanisation of the 1960s and 1970s. As a socially selective suburbanisation led to the development of urban regions, central cities suffered from the loss of higher income groups to suburban municipalities: they experienced a comparatively slower growth of their tax base while still having to provide many public facilities to its own inhabitants and the rest of the city region. The opposite applies to the suburban municipalities, who enjoyed relative high incomes and a low level of costs. Local representatives of suburban municipalities, who make up the majority in the national parliament therefore continuously opposed any attempt to local autonomy, be it the formation of greater city regions or the development of a national policy confronting central city problems. Attempts to consolidate municipalities between 1977 and 1983 (see Ackaert \& Dekien, 1989), primarily motivated by arguments of functional efficiency did succeed in reducing the number of small independent municipalities, but failed to create true city regions because of this local opposition.

Lievens e.a. (1975) showed how action groups fought their struggles mainly on the local scale because territorial fragmentation of policies reduced their power on the national scale. Yet because of their weakening financial position, urban or industrialised municipalities were more sensible to the demands of speculators and investors than of the own, mostly low-income population. As late as the 1980s, urged by the European urban renewal campaign between 1980 and 1982, the first concrete steps towards urban renewal on a human scale were taken in Belgium. Meanwhile, the federalisation process that took off in the 1970s had devolved responsibilities regarding urban renewal and planning to the regional level in 1974. It was thus the Flemish Council who showed interest in a «social» and small-scale version of urban renewal for the first time (Secretariaat stadsvernieuwing, 1981). The Christian-democratic minister Akkermans raised a fund to support local urban renewal projects that favoured an «integral approach to deprived areas in cities or villages, in collaboration and dialogue with the local residents». The fund supported small-scale building and renovation projects focused on 
housing, in line with the historical structure of the environment and addressing local needs only (Knops \& Vlaeminck, 1983; Heughebaert, 1988).

However this «social renewal policy» had little effect. Compared to the intense cuts in social expenses at the time (social housing for instance faced a virtual standstill in the 1980s), there was little money available (a maximum of 600 million BEF or 15 million EURO in the first year, compared to for instance 6 billion or 150 million EURO in 1986 in the Netherlands). Given the dominance of the suburban municipalities in the parliament and the rural dominance of the Christian-democrats, it was impossible to aim the fund explicitly at urban problems. Therefore all Flemish municipalities, rich and poor, were allowed to subscribe. This resulted in very different levels of deprivation among the selected areas: disadvantaged neighbourhoods were selected at the local level, deprivation was measured in comparison with the average of the district. Thus many of the most needy areas in Flanders were not selected in favour of areas that were lagging behind compared to the local situation, but scored above average compared to the overall Flemish situation (Heughebaert, 1988).

After the 1985 elections, liberal ministers became responsible for urban renewal and aborted this preliminary attempt of urban policy because it was too «state-controlled» and put too much emphasis on social housing (Heughebaert, 1988; De Decker, 1986; 1994). An evaluation of the social urban renewal policy looks poor: Only 44 of the 151 selected areas reached the operational stage while the most deprived areas had not even received recognition. Social urban renewal in Flanders did not succeed in addressing the needs of the most deprived areas and the poorer inhabitants of the selected areas. Large-scale participation of inhabitants in projects that were soon left to their fate created a lot of frustrations (De Decker, 1994). Yet the social renewal policy had succeeded to bring institutions and actors concerned with the fate of disadvantaged neighbourhoods into the newly developing Flemish administration, who recruited eagerly among politically active members of the new social (urban) movements (Stouthuysen e.a., 2000). While this alone does not guarantee a change in politics, an electoral earthquake quite unexpectedly offered them the opportunity to bring their ideas to the fore on the regional and national level.

\section{Jumping scales on the back of the Vlaams Blok}

\section{Black Sunday or. how disad-vantaged neighbourhoods came on the political agenda}

Alongside the failure of the social renewal policy, a new political phenomenon emerged: the electoral rise of the extreme-right party Vlaams Blok (VB). It is the electoral threat of the VB that would finally provoke greater attention to the problems of inhabitants of disadvantaged neighbourhoods because of the high percentage of extreme-right votes obtained there. The party scored its first successes in Antwerp, the largest Flemish city. While at first only noticed on a local level, the VB quickly rose to become a regional, if not national threat to political stability. Their first major political breakthrough at the local elections of 1988, when VB obtained 17\% of the votes in Antwerp, came like a bolt from the blue. However it is the elections of November 24, 1991 that are commonly mentioned as a turning point: the VB obtained more than $10 \%$ of all the Flemish votes and rose from 
a local «problem» to a national one. This day has been referred to as «Black Sunday», an epithet that has been used for every electoral victory of the party ever after.

Despite the steady rise of votes for the $V B$, they have never been able to govern, even at the local level. To secure political stability, the other parties engaged in a cordon sanitaire, a treaty prohibiting any collaboration with the VB. However, the VB influenced governmental decisions indirectly. In order to divert votes away from the VB, the established parties were sensitive to the issues raised by the $V B$, trying to incorporate these themes in their own discourse. Thus politicians and social scientists engaged in intense debates about the «reasons» behind the electoral successes of the VB in order to formulate their own solutions to it and undermine the party's success. Three main interpretations were put forward (Witte e.a., 1997):

- Some interpreters partially adopt elements of the extreme-right discourse, relating the rise of the VB to the «migrant question», «petty crime», «feelings of insecurity» etc. This interpretation inspired some policy measures (mainly at the federal -Belgian- level) that try to combine a more repressive approach to crime with measures to enhance intercultural tolerance.

- Another explanation emerged from the ideas of the new social movements of the 1970s. According to Stouthuysen e.a. (2000) they were, partly because of their infiltration in the Flemish administration and party structures able to bring their «structural» analysis to the attention of the Christian-democratic and socialist politicians that took power in 1988. This interpretation blames social exclusion, poverty, the destruction of social networks and social cohesion, anomy for the electoral success of the VB. They focus on the unequal distribution of «chances» across the population. The living conditions in deprived (urban) neighbourhoods make up an important element of these chances (see for instance Swyngedouw, 1989; 1990; 1992).

- A third explanation relates the electoral rise of the $V B$ as an expression of anti-political or anti-democratic feelings related to the gap between politics and the civilian. Inefficient and inaccessible facilities and a lack of participation possibilities undermine the legitimacy of the political system and created the feeling that politics largely neglected the people. Again this interpretation has some ties to the discourse of social exclusion. More specifically concerning urban policy, De Decker (1999a) relates extreme-right voting in disadvantaged urban neighbourhoods to the failure of participation in the social urban renewal policy.

The last two explanations quickly dominated the discourse of the Christian-socialist coalition in Flanders. Overall political analysts sustained the view that the poor had grabbed the VB as a lever to ask for attention to their problems, making the VB the catalyst to bring the «new social question» on the political agenda. Their radical change of voting behaviour made marginal groups the centre of attention, on the regional as well as the national level (Vranken \& Geldof, 1991; p. 102). Several initiatives were set up focusing on the problems of marginal groups or insisting on the necessity of «narrowing the gap» between politics and civilians. Because extreme-right parties were much less of a threat in Wallonia and Brussels (see CEPESS, 2000), the most important measures were taken in Flanders (Witte e.a., 1997). Though the social urban renewal policy was petering out, a new and more ambitious initiative saw the light under the wings of this new Flemish government in 1989. More than 2.2 billion BEF (55 million EURO) per year received as a compensation for dept redemption for Walloon cities, was used to set up a policy combating social exclusion. The policy had to be pursued at the local level in order 
to be more efficient and responsive to local needs and to make political actions more visible so as to reinforce legitimacy.

Whereas the socialist party, suffering the most from the electoral rise of the $V B$, was sensitive to the demand for a selective distribution of the money favouring the most needy municipalities, other parties advocated to allow all 298 municipalities a share. Intense political struggle and some improvised attempts (see Vranken \& Geldof, 1991; 1993) led in 1991 to a «Flemish Fund for the Integration of the Underpriviliged» (Vlaams Fonds voor de Integratie van Kansarmen-VFIK). This Fund received 1.218 billion BEF to combat exclusion in 15 communities and cities with the largest concentration of poor and immigrant communities. The other half of the bonus, another 1.218 billion was divided among the other 283 Flemish communities. This VFIK was the first fund to explicitly prioritise cities with the highest poverty levels. It cranked up discussions about poverty at the regional and local level, obliging local administrations to take measures against poverty and deprivation in exchange for money.

Nonetheless, the VFIK received heavy critiques. In 1995, a rather critical evaluation by a multidisciplinary team of academics was a welcome excuse for the newly appointed government to abolish the VFIK and come up with a new initiative (Vranken e.a., 1995). A central objection to the VFIK was the lack of a «structural» and «integrated» approach to poverty dispersing means among too many, unrelated and often temporary projects. The VFIK was also found too much oriented towards the social sector, and did not succeed in luring other sectors in. There was no attention for crucial elements like job creation and housing (Baert \& Fauconnier, 1995). Moreover the VFIK did not seem to score any electoral effect: on another «Black Sunday» in 1995, the VB again achieved spectacular results.

The VFIK-approach in Antwerp though did command esteem. An independent umbrella organisation, the BOM (Buurt-OntwikkelingsMaatschappij or neighbourhood development corporation) merged projects funded with Flemish (VFIK), federal as well as European (URBAN I) means in one integral «neighbourhood development project», not restricted to the welfare sector, but including housing, economy and urban planning (Hobin, 1995; Van Hove \& Nieuwinckel, 1996). This approach inspired the Flemish government to set up similar «social renewal»-experiments in other cities (Ghent, Genk, Louvain and Mechelen) in 1994.

\section{The genesis of an urban policy in Flanders: the Social Impulse Fund}

After another electoral victory of the VB in 1995, urban policy became a top priority for the new Flemish government (Vlaams Parlement, 1996). The first Flemish minister for urban policy was appointed. The means of the VFIK were merged with other existing funds and new means into a new «Social Impulse Fund» (SIF). While VFIK flavoured social policy with a territorial touch, focusing on cities with high poverty concentrations, the new fund would become the spearhead of what was meant to be the first multidisciplinary and multifaceted urban policy in Flanders (see Peeters, 1996; De Decker, 1999b). By merging different funds in one SIF and adding new means, the budget for urban policy greatly increased. Starting with 4.5 billion BEF (112.5 million EURO) in 1996, it would increase with 1 billion BEF per year up to 7.5 billion BEF (187.5 million EURO) in 1999. 

under the wings of the BOM, as well as the «integral approach» of the Dutch " Grotestedenbeleid» (Large Cities Policy), the SIF would put more stress on territorial and integral measures than its VFIK-forerunner. The goals of the SIF were threefold: the improvement of the life-quality in disadvantaged neighbourhoods and cities, the war on poverty and the promotion of well-being (Belgisch Staatsblad, 1996). The SIF aimed to advance a physical, social and economic restructuring of cities (De Decker e.a., 1996). Yet at the same time, poverty and deprivation were able to stay at the heart of SIF. This report, ordered by the federal government after the first Black Sunday, drew attention nation-wide because the poor themselves were asked to speak out about the causes of poverty and the exclusionary mechanisms experienced. Unexpectedly the report got a lot of feedback on different policy levels (Neirinckx, 1995) and fed the «structural» interpretation of the VB's electoral successes. The social- and Christiandemocratic parties, facing the new electoral victory of the extreme-right party, decided to dedicate SIF to be a «specific response to the conclusions of the AVA» (Vlaams Parlement, 1996). The minister for urban policy proclaimed repeatedly that poverty and deprivation had to be the main focus of the SIF, and that the means should be directed towards the poorest neighbourhoods and the poorest people (Vlaamse Raad, 1995; Vandenberghe, 1997). To emphasise this promise, separate means were provided in order to support associations of poor people to participate in the development and evaluation of the SIF at the Flemish level.

In order to secure this poverty approach, the Flemish government applied a relatively elaborated top-down approach. First of all, this involved a strong selectivity in funding. Like VFIK, SIF used poverty criteria to select municipalities for funding and to decide on the level of funding per municipality (De Coninck \& Vandenberghe, 1996). Secondly, a special SIF-administration was set up in order to control the local expenditures. Every municipality is obliged to draw up a detailed SIF-policy plan that has to be confirmed by the Flemish government in a written agreement between the Flemish and the local level. The plan has to depart from an analysis that pays explicit attention to the «needs concerning poverty, employment and unemployment, housing and social deprivation in the municipality» (Belgisch Staatsblad, 1996).

31 This top-down approach was warmly acclaimed by local actors and institutions concerned with problems of poverty and social exclusion (De Decker e.a., 2002). The VFIK and SIF enforced attention to the needs of marginal groups on the local level, as these issues were often intentionally neglected before. The explicit poverty approach of the SIF gave these institutions great power and influence on the local level. Since most local administrations had little know-how concerning poverty and social exclusion, they were eager to pass-on their urban policy assignment to local poverty institutions. This enabled the expansion of staff in the non-or semi-governmental organisations involved. (The growing employment in the sector was even criticised for absorbing a too large proportion of the budget.) In a number of municipalities they developed into powerful local institutions, relatively independent from the political sphere. By dominating the SIF, these institutions successfully influenced the local political agenda. One of the SIF-co-ordinators called herself the «mole» in the heart of the local administration, inspiring them to discover the problem of poverty and deprivation (Kesteloot e.a., 2002). 


\section{Another twist}

\section{New electoral developments and urban policy reforms}

After another Black Sunday in 1999, it became clear that the «war on poverty» did not drive back the VB. Furthermore, the extreme-right party succeeded to gain more and more votes among the well-to-do and in suburban districts (Kesteloot \& De Decker, 1992; Vlaams Parlement, 1996; De Maesschalck, 2000). This conclusion takes the VB as a political weapon out of the hands of the urban poor.

Simultaneously, the liberal party re-entered the government after ten years. Both events enhanced a shift away from poverty alleviation to measures to enhance security and quality of life, in order to counter the VB. This policy turn is reflected in the urban policy reform as announced by the new Flemish government in its inaugural speech (Vlaamse Regering, 1999). The main goal in urban policy is reformulated as "countering the depopulation of urban areas by enhancing the quality of life», more specifically for young families, middle- and high income groups and «active» seniors (Van Grembergen, 2001). This policy shift was welcomed by many local governments who, facing a fiscal crisis due to selective suburbanisation, preferred an «urban» above a «social» definition of the SIFassignment (Boudry e.a., 1999). After having been the heroes of urban policy in Flanders for a long time, poor people seem to be back to zero again (Loopmans, 2002): they have lost attention at the regional level and are only mentioned in the new plans in so far as displacement or segregation is feared. It is telling for this turn that the new minister of urban policy decided to stop funding collaboration with associations of poor people in the development of urban policy.

Some small initiatives, more a matter of prestige, have been taken, such as the conception of the first Flemish White Paper on Urban Policy (to appear only in 2003, after all the reforms are settled) or a small-scale (25 million EURO) once-only competitive bidding programme for public-private partnership urban development projects (Vlaamse Regering, 2001a). But the most influential changes are expected from the reform of the SIF in 2003. Half of the SIF-budget will be diverted to the «Municipality Fund», a fund distributing money among municipalities according to their (predominantly financial) needs (Vlaamse Regering, 2001b). Contrary to the SIF, no top-down directions on the use of the means are formulated, making it appear that the Flemish government is mainly giving in to the local demand for more autonomy. Given local laments on the «social» approach of SIF, this increase of local autonomy is suspected to divert attention away from disadvantaged neighbourhoods towards more promising locations (De Decker, 2002; Van Menxel, 2002; Loopmans, 2002; De Decker \& Loopmans, 2003).

The remaining SIF-budget will be turned into an «Urban Fund». This Urban Fund is no longer exclusively aimed at the poor and needy. Being the most important instrument for urban policy, this will primarily serve to enhance the quality of life in cities for the current, as well as for the potential population of cities. More specifically, the Fund is aimed at attracting middle- and high income groups to the city (Vlaams Parlement, 2002).

This new goals are reflected in the new criteria for the distribution of the Fund: municipalities are no longer selected on the base of needs, but on their position in the Flemish urban hierarchy (Van Grembergen, 2001). Moreover municipalities are incited to 
restrict neighbourhood development no longer to the most needy areas, in order to prevent future downgrading in other neighbourhoods (Vlaams Parlement, 2002).

The new goals for urban policy in Flanders show how actors concerned with the fate of disadvantaged areas and the poor have lost much influence at the regional scale. Yet at the local scale, their position seems to have strengthened during the SIF-period: Local administrations willing to cut funding for «social projects» under the future Urban Fund face fierce opposition by the institutions involved in the SIF. SIF-employees strike to secure their jobs and local social institutions mobilise the public opinion and the media (e.g. Van Houtte, 2002) as well as their political allies (see De Standaard, 2002). Thus local social institutions that developed and grew under the SIF might make up a new element of path dependency in urban policy, but it is currently still hard to tell to what extent they will be able to exert influence on local political decisions.

\section{Conclusion}

As has been said in section 1, debates on re-scaling generally follow the pattern of critical state theorizing in that it is possible two discern two positions: one emphasises political struggles (and hence contingency), the other structural imperatives (and hence similarities). However, in practice all authors writing about re-scaling recognise that both political struggles and general shifts in the development of capitalism are important for understanding processes of re-scaling. In this paper, we have tried to show how this general observation could be more concrete for the Belgian (Flemish) case.

We have shown how, under structural imperatives of Fordism and as a result of political struggles to secure political dominance for the Catholic party, a national policy confronting specific urban problems was not likely to emerge in Belgium or Flanders. In the 1960s and 1970s grassroots struggle and the emergence of new urban social movements spurred the development of an explicitly urban policy in other European countries. In Belgium however, the territorial fragmentation and the numeric dominance of suburban representatives in the national parliament thwarted attention for specific urban problems at the national level in Belgium. Apart from a -for the same reasons- very modest and prematurely ended Flemish attempt urged by a European campaign, a path dependent anti-urban policy continued until the end of the 1980s.

The electoral rise of the VB which started in disadvantaged neighbourhoods in Antwerp and other cities by the end of the 1980s caused the rupture that spurred growing attention for urban needs. The concentration of the VB electorate in cities enabled actors concerned with the faith of disadvantaged neighbourhoods and urban poor to jump scales and draw political attention at a national and regional level. They provide the Flemish government with an alternative discourse on urban problems focusing on poverty and social exclusion and largely influence the content of an urban policy (SIF) that by its topdown approach strengthened their position at the local level as well.

The introduction of the liberal party in government in 1999 brought along a reform of urban policy and can be seen as a smaller, but not insignificant «rupture» in the development of urban policy in Flanders. The fact that the VB is still powerful in the cities and even attracts more and more voters from higher income groups and in suburban districts, called for another approach as well. The emphasis is now on the «repopulation» of the city centre by middle and high-income groups and poorer city dwellers disappear 
from view on the Flemish level. This new approach was welcomed by many local governments, facing fiscal pressure from ongoing suburbanisation. Yet on the same local level, the social institutions involved in the SIF seem to have become «incontournable» for local politicians. They currently put a lot of pressure on the local administrations to keep the new Urban Fund as «socially» orientated as possible and seem to have become an element of path-dependency in urban policy in Flanders.

\section{BIBLIOGRAPHY}

ACKAERT J. \& DEKIEN C. (1989), Samenvoeging van gemeenten: verandering in de gemeentelijke organisatie en beleidsvoering, Leuven, KULeuven (un-published research report).

BAERT H. \& FAUCONNIER E. (1995), De doelbepaling en doelgroepkeuze in enkele VFIK-gemeenten, Leuven, LUCAS (unpublished research report).

BELGISCH STAATSBLAD (1996), Decreet tot vaststelling van de regelen inzake de werking en de verdeling van het Sociaal Impuls Fonds, Brussel, Belgisch Staatsblad.

BOUDRY L., DE CONINCK M., FRET L., GELDOF D., GOOSSENS J., NOTREDAME L., SALMON P., SEYS P., VAN BELLEGHEM S., VANDENBERGHE J., VANDENBUS-SCHE J. \& YSEBIE P. (1999), «Sociale, stedelijke en bestuurlijke ontwikkeling? Een tussentijdse SIF-balans, verslag van een rondetafelgesprek over de SIF-effecten 1997-1999», Alert, 25, 1, pp. 21-48.

BRENNER N. (1998), «Global cities, glocal scales: global city formation and state territorial restructuring in contemporary Europe», Review of International Political Economy, 5, pp. 1-37.

BRENNER N. (1999), «Globalisation as reterritorialisation: the re-scaling of urban governance in the European Union», Urban Studies, 36, pp. 431-451.

BRENNER N. (2001), «The limits to scale? Methodological reflections on scalar structuration», Progress in Human Geography, 25, 4, pp. 591-615.

CEPESS (2000), L'extrême-droite en Europe et en Belgique. Etat des lieux et des stratégies, Brussels, CEPESS.

CHESHIRE P.C. \& HAY D.G., Urban problems in Western Europe: an economic analysis, London, Unwin Hyman.

COLLINGE C. (1999), «Self-organization of society by scale: a spatial reworking of regulation theory», Environment and Planning D: Society and Space, 15, pp. 554-574.

DE CONINCK M. \& VANDENBERGHE J. (1996), Het Sociaal Impulsfonds: een instrument voor het stedelijk beleid, Brussel, Ministerie van de Vlaamse Ge-meenschap.

DE DECKER P. (1986), «Tegelijk remmen en gas geven: beschouwingen over het ruimtelijk beleid voor stad en stadsgewest in Vlaanderen», Planologisch Nieuws, 6, 3, pp. 114-131.

DE DECKER P. (1994), «Het herwaar-deringsbesluit geherwaardeerd?» Ruimtelijke planning, katern 2 , pp. 85-93. 
DE DECKER P. (1999a), «De stadsmus raakt zelfs zijn bomen kwijt», in WIES-BAUER N. (red.), Gazet van Babel. Een docudrama in 6 brieven en 5 seizoenen, Antwerpen, vzw de Kersentuin, p. 39-46.

DE DECKER P. (1999b), «On the Genesis of an Urban Policy in Flanders, Belgium», Netherlands Journal of Housing and the Built Environment, 14, 2 , pp. 183-190.

DE DECKER P. (2002), «De kracht van de context», Ruimte en Planning, 20, 2.

DE DECKER P., HUBEAU B. \& NIEUWINCKEL S. (1996), «Stedelijke ver-nieuwing: eindelijk de retoriek voorbij?», in DE DECKER P., HUBEAU B. en NIEUWINCKEL S. (red.), In de ban van stad en wijk, Berchem, EPO.

DE DECKER P. \& LOOPMANS M. (2003), «Terug naar af? Over armoedebestrijding in het Vlaamse stedenbeleid», Agora, 19, 1 (forthcoming).

DE DECKER P., VAN NIEUWENHUYZE I. \& VRANKEN J. (2002), Urban Development programmes in Flanders; Ghent and Antwerp. A preliminary assessment, working paper for UGIS (urban development programmes, urban governance, social inclusion and sustainability) (EVK4-CT-1999-00012 UGIS), Leuven, Acco (forthcoming).

DE LANNOY W. \& KESTELOOT C. (1990), «Het scheppen van sociaal-ruimtelijke ongelijkheden in de stad», in Mort Subite (red.), Barsten in België, Berchem, EPO.

DE MAESSCHALCK F. (2000), «Electo-rale geografie van het Vlaams Blok, de ruimtelijke evolutie van de verkiezingsuit-slagen van 1981 tot en met 1995», De Aardrijkskunde, 24, 1-2, pp. 21-36.

DE STANDAARD (2002), «Antwerpse onenigheid over Stedenfonds», De Standaard, 28-05-2002.

DEVOS C. (2001), «Machtsrelevantie van multi-level structuren: een algemene verkenning», Res Publica, 43, pp. 81-101.

GIDDENS A. (1984), The constitution of society: outline of the theory of structuration, Cambridge, Polity Press.

HEUGHEBAERT M. (1988), Inspraak van bewoners in het nieuwe stadsontwikke-lingsbesluit, toespraak op de studiedag stadsontwikkeling, Congrespaleis Gent, 23 september 1988.

HOBIN V. (1995), «Wijkontwikkeling: in de ban van de wijk», in VRANKEN J., GELDOF D. \& VAN MENXEL G. (eds.), Armoede en sociale uitsluiting, jaarboek 1995, Leuven, Acco.

JESSOP B. (1982), State theory: putting the capitalist state in its place, Cambridge, Polity Press.

JESSOP B. (1990), The capitalist state, Oxford, Martin Robertson.

JESSOP B. (1994), «Post-fordism and the state», in AMIN A. (ed.), Post-Fordism, a reader, Oxford, Blackwell, 251-279.

JESSOP B. (2001), «Institutional (re)turns and the strategic-relation approach», Environment and Planning A, 33, pp. 1213-1235.

JONES M. (1997), «Spatial selectivity of the state? The regulationist enigma and local struggles over economic governance», Environment and Planning A, 29, pp. 831-864.

KESTELOOT C. \& DE DECKER P. (1992), «Territoria en migraties als geografische factoren van racisme», in DESLÉ E. \& MARTENS A. (red.), Gezichten van hedendaags racisme, Brussel, VUB Press, pp. 69-108.

KESTELOOT C. \& DE MAESSCHALCK F. (2001), «Anti-Urbanism in Flanders: the political and social consequences of a spatial class struggle strategy», Belgeo, 1-2, pp. 41-62. 
KESTELOOT C., SAEY P., DE MAES-SCHALCK F., LOOPMANS M., UITERMARK J., DENAEYER W., MISTIAEN P. \& F. GUL-DENTOPS (2002), Achtergestelde buurten, economische integratie en stedelijk beleid, unpublished report, Leuven, KULeuven.

KNOPS G. (1981), «Stadsvernieuwing in België tussen het midden van de negentiende eeuw en 1953», Ruimtelijke plan-ning, 1981-1, pp. 1-18

KNOPS G. \& VLAEMINCK S. (1983), «Sociale stads- en dorpsvernieuwings-operaties», Ruimtelijke planning, afl. 6, II.A.1.e., pp. kno1-kno19.

LIEVENS J., BRASSEUR N. \& MARTENS A. (1975), De grote stad: een geplande chaos?, Leuven, Davidsfonds.

LIPIETZ A. (1992), «The regulation approach and capitalist crisis: an alternative compromise for the 1990s», in DUNFORD M. \& KAFKALAS G. (eds.), Cities and regions in the New Europe, London, Belhaven Press, pp. 309-334.

LOOPMANS M. (2002), «From hero to zero. Armen en stedelijk beleid in Vlaanderen», Ruimte en planning, 22, 1, pp. 39-49.

MACLEOD G. \& GOODWIN M. (1999), «Space, scale and state strategy: rethinking urban and regional governance», Progress in Human Geography, 23, pp. 503-527.

MASSEY D. (1993), «Power-geometry and a progressive sense of place», in BIRD J., CURTIS B., PUTNAM T., ROBERTSON G., TICKNER L. (eds.), Mapping the futures: local cultures, global change, London, Routledge, pp. 59-69.

NEIRINCKX P. (1995), «Het Algemeen Verslag over de Armoede: betekenis en opvolging», in VRANKEN J., GELDOF D. \& VAN MENXEL G. (eds.), Armoede en sociale uitsluiting, jaarboek 1995, Leuven, Acco.

PEETERS L. (1996), Voor Steden en Mensen: beleidsbrief 1995, Brussel, Ministerie van de Vlaamse Gemeenschap.

PIERSON P. (2000), «Increasing returns, path dependence and the study of politics», American Political Science Review, 92, pp. 251-267.

POULANTZAS N. (1978), State, power, socialism, London, Verso.

SECRETARIAAT STADSVERNIEUWING (1981), Stadsvernieuwing is ieders zaak: een werkboek voor plaatselijke groepen, Brussel, Koning Boudewijnstichting.

SMITH N. (1993), «Homeless/global: scaling places», in BIRD J., CURTIS B., PUTNAM T., ROBERTSON G., TICKNER L. (eds.), Mapping the futures: local cultures, global change, London, Routledge, pp. 87-120.

SMITH N. (1995), «Remaking scale: competition and cooperation», in ESKELINEN H. \& SNICKARS F. (eds.), Competitive European peripheries, Berlin, Springer, pp. 59-74.

STOUTHUYSEN P., DUYVENDAK J.W. \& VAN DER GRAAF P. (2000), «Stedelijk beleid in Vlaanderen en Nederland: kans-armoede, sociale cohesie en sociaal kapitaal», in HOOGHE M. (ed.), Sociaal kapitaal en democratie, Leuven, Acco, pp. 365-394.

SWYNGEDOUW E. (1992), «The Mammon Quest. 'Glocalization', interspatial competition and the monetary order: the construction of new scales», in DUNFORD M. \& KAFKALAS G. (eds), Cities and regions in the New Europe, London, Belha-ven Press, pp. 39-67.

SWYNGEDOUW E. (1997a), «Neither global nor local: glocalization and the politics of scale», in COX K.R. (ed.), Spaces of globalization; Reasserting the power of the local, New York, The Guilford Press, pp. 137-177. 
SWYNGEDOUW E. (1997b), «Excluding the other: the production of scale and scaled politics», in LEE R. \& WILLS J. (eds.), Geographies of economies, London, Edward Arnold, pp. 167-177.

SWYNGEDOUW E. (2000), «Authoritarian governance, power and the politics of re-scaling», Environment and Planning D: society and space, 18, pp. 63-76.

SWYNGEDOUW M. (1989), De keuze van de kiezer, Leuven, Departement Sociolo-gie/Sociologisch Onderzoeksinstituut.

SWYNGEDOUW M. (1990), «Verkiezingen in Antwerpen: Het Vlaams Blok, Islamitische minderheden en kansarmoede», Tijdschrift voor sociologie, 11, 5-6. pp. 401-429

SWYNGEDOUW M. (1992), Waar voor je waarden: De opkomst van Vlaams Blok en Agalev in de jaren '80, Leuven, Departement Sociologie/Sociologisch Onder-zoeksinstituut.

TERHORST P. \& VAN DE VEN J. (1997), «Fragmented Brussels and consolidated Amsterdam, a comparative study of the spatial organisation of property rights», Nederlandse Geografische Studies, 223, Koninklijk Nederlands Aardrijkskundig Genootschap/ Instituut voor Sociale Geografie, Amsterdam, Universiteit van Amsterdam.

TERHORST P. \& VAN DER VEN J. (1999), «Stedelijke Ontwikkelingspaden, Regimes en Eigendomsrechten: Brussel en Amsterdam Vergeleken», Planologisch Nieuws, 19, 4, pp. 342-366.

UITERMARK J. (2002a), «Re-scaling, 'scale fragmentation' and the regulation of antagonistic relationships», Progress in Human Geography, 26, pp. 743-765.

UITERMARK J. (2002b), «Spatial policy in the United Kingdom: Regulatory experimentation in the after-Fordist era», Journal of Housing and the Built Environment, 17, pp. 385-407.

UITERMARK J. (2003a), De sociale controle van achterstandswijken: een beleidsgenetisch perspectief, M.A. Thesis, Amsterdam: University of Amsterdam.

UITERMARK J. (2003b), «Social mixing and the management of disadvantaged neighbourhoods: the Dutch policy of urban restructuring revisited», Urban Studies, 40 (forthcoming).

VANDENBERGHE J. (1997), «Bestuurlijke dialoog in een verantwoordelijke samenleving», Alert, 23, 1, pp. 43-47.

VAN GREMBERGEN P. (2001), Beleidsbrief binnenlandse aangelegenheden en stedenbeleid 2001-2002, Brussel, Ministerie van de Vlaamse Gemeenschap.

VAN HOUTTE R. (2002), «Zou Antwerpen stilaan beseffen welke prijs er betaald is voor de prioriteit aller prioriteiten?», Gazet van Antwerpen, 6-05-2002.

VAN HOVE E. \& NIEUWINCKEL S. (1996), Het Bomboek: het verhaal van de buurtontwikkelingsmaatschappij Noordoost-Antwerpen, Brussel, Koning Boudewijn-stichting.

VAN MENXEL G. (2002), «Is er nog plaats voor armoedebestrijding in het lokaal sociaal beleid?», in VRANKEN J., DE BOYSER K., GELDOF D. \& VAN MENXEL G. (eds.), Armoede en sociale uitsluiting, jaarboek 2002, Leuven, Acco, pp. 263-276.

VLAAMSE RAAD (1995), Plenaire vergadering: handelingen $n r .3$, vergadering van 21 juni 1995, Brussel, Vlaams Parlement.

VLAAMSE REGERING (1999), Regeerakkoord voor Vlaanderen: Een nieuw project voor Vlaanderen, Brussel, Ministerie van de Vlaamse Gemeenschap.

VLAAMSE REGERING (2001a), Ontwerp van decreet houdende de ondersteuning van stadsvernieuwingsprojecten, Brussel, Ministerie van de Vlaamse Gemeenschap. 
VLAAMSE REGERING (2001b), Nieuw Vlaams Gemeentefonds vermindert regelgeving en versterkt gemeentelijke autonomie, persmededeling van de Vlaamse Regering, Brussel, Ministerie van de Vlaamse Gemeenschap.

VLAAMS PARLEMENT (1996), Plenaire vergadering: handelingen 39, vergadering van 7 mei 1996, Brussel, Vlaams Parlement.

VLAAMS PARLEMENT (2002), Plenaire vergadering, decreet tot vaststelling van de regels inzake werking en verdeling van het Vlaams Stedenfonds, vergadering van 4 december 2002, Brussel, Vlaams Parlement.

VRANKEN J. \& GELDOF D. (1991), Armoede en sociale uitsluiting, jaarboek 1991, Leuven, Acco.

VRANKEN J. \& GELDOF D. (1993), Armoede en sociale uitsluiting, jaarboek 1992-93, Leuven, Acco.

VRANKEN J., GELDOF D. \& VAN MENXEL G. (1995), Armoede en sociale uitsluiting, jaarboek 1995, Leuven, Acco.

WITTE E., CRAEBECKX J. \& MEYNEN A. (1997), Politieke geschiedenis van België van 1830 tot heden, Antwerp, Standaard Uitgeverij.

\section{NOTES}

1. Such critical conjunctures have been analysed extensively by regulationist theorists in the context of the demise of Fordism (e.g. Lipietz, 1992; Jessop, 1994). Swyngedouw has developed the most extensive discussion of scalar reconfigurations from a regulationist viewpoint (Swyngedouw, 1992, 1997a).

\section{ABSTRACTS}

Theorising on politics of scale falls in two general categories: class-theoretical (actor-) and capital-theoretical or structural approaches. We discuss how notions of «path-dependency» and «critical conjunctures» can serve as a means to transcend the discrepancies between both approaches. Our analysis of the emergence of an urban policy in Flanders, Belgium shows how a path-dependent development of anti-urban politics was interrupted and changed into a deliberately urban focus when political stability was threatened by the sudden electoral successes of the extreme-right party Vlaams Blok in Flanders. Actors concerned with the fate of disadvantaged neighbourhoods grabbed this chance to build up power at the regional (Flemish) level and managed to influence form and content of the established urban policy. By imposing a top-down approach, they equally strengthened their position at the local level. New developments in 1999 have diminished their power at the regional level, but at the local level, their institutional materialisations now seem to constitute a new element of path dependency in many municipalities.

Theorieën over schaalpolitiek zijn in te delen in twee categorieën: klasse-theoretische of actorbenaderingen en kapitaal-theoretische of structuurbenaderingen. In dit artikel betogen we dat concepten als padafhankelijkheid en crisissituaties een brug kunnen vormen tussen beide benaderingen. In een analyse van het ontstaan van stedelijk beleid in Vlaanderen gaan we na hoe 
een padafhankelijke ontwikkeling van anti-stedelijk beleid werd onderbroken en omsloeg in een nadrukkelijke aandacht voor steden onder politieke druk van de extreem-rechtse partij Vlaams Blok in Vlaanderen. Maatschappelijke actoren met oog voor achtergestelde buurten grepen deze kans om macht op te bouwen op regionaal (Vlaams) niveau en slaagden erin vorm en inhoud van het zich vormende stedelijk beleid te beinvloeden. Door een sterke controle uit te oefenen vanop Vlaams niveau konden ze ook hun positie versterken op lokaal niveau. Nieuwe ontwikkelingen in 1999 ondergroeven evenwel hun machtspositie op regionaal niveau. In verschillende gemeenten lijken hun institutionele materialisaties echter een nieuwe vorm van padafhankelijkheid te vormen.

Il y a deux manières de théoriser sur la politique d'échelle: à l'aide de théories de classe d'une part et à l'aide de théories de capital d'autre part. Nous examinons comment les idées de "path dependency» et de «conjonctures critiques» peuvent être utilisées pour transgresser les différences entre les deux. Notre analyse de la naissance d'une politique urbaine en Flandre, une des trois régions de la Belgique, montre comment un développement «path dependent» d'une attitude anti-urbaine dans la politique flamande et belge a été interrompu et s'est transformé en une attention consciente pour la ville, notamment lorsque la stabilité politique était menacée par le succès soudain d'un parti à tendance d'extrême-droite «Vlaams Blok» en Flandre. A cette occasion, des acteurs préoccupés par le sort des quartiers défavorisés ont réussi à s'attribuer du pouvoir au niveau de la Flandre et ainsi à influencer la forme et le sens de la politique urbaine qui était en exécution. En imposant une approche «top-down», ils ont pu renforcer aussi leur position au niveau local. Les nouveaux développements en 1999 ont diminué leur pouvoir au niveau régional, mais au niveau local, leurs matérialisations institutionnelles semblent constituer un élément nouveau de «path dependency» dans différentes communes.

\section{INDEX}

Mots-clés: politique d'échelle, politique urbaine, Vlaams Blok, Flandre, Belgique

Keywords: re-scaling, urban policy, Flanders, Belgium

motsclesnl herschaling, stedelijke politiek, Vlaanderen, België

\section{AUTHORS}

\section{MAARTEN LOOPMANS}

Aspirant FWO-Vlaanderen, Institute for Social and Economic Geography, Catholic University of Louvain, Belgium, Maarten.Loopmans@geo.kuleuven.ac.be

\section{JUSTUS UITERMARK}

Department of Geography and Planning, University of Amsterdam, The Netherlands, juitermark@fmg.uva.nl

\section{FILIP DE MAESSCHALCK}

Institute for Social and Economic Geography, Catholic University of Louvain, Belgium, Filip.DeMaesschalck@geo.kuleuven.ac.be 